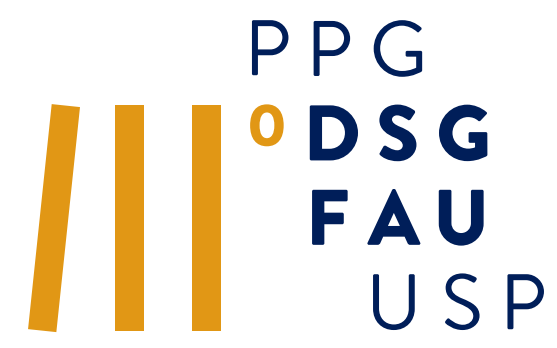

PAULO CELSO

MARCONDES

DE SALLES

\section{CIBELE HADDAD}

TARALLI

NÍVEL DE PESQUISA

RESEARCH LEVEL

MESTRADO

MASTER

\section{PAULO CELSO MARCONDES DE SALLES}

Arquiteto, graduado pela Faculdade de Arquitetura e Urbanismo de Santos, 1983; Atua em consultorias, e projetos de acústica arquitetônica e eletroacústica, arquitetura, urbanismo, design gráfico, luminotécnica, iluminação cênica, arquitetura cênica, cenotecnia e cenografia, design de móveis e painéis técnicos acústicos,; Mestrando em Design Acústico pela FAUUSP, 2018-2020.

Architect, graduated from the FAU/Santos, (1983); works in consultancies and projects of architectural and electroacoustic acoustics, architecture, urbanism, graphic design, lighting engineering, scenic lighting, scenic architecture, scenography and design, furniture design and acoustic technical acoustics panels; Master's degree in Acoustic Design at the FAUUSP, 2018-2020)

paulosalles@usp.br

lattes.cnpq.br/

2908913931989849

\section{CIBELE HADDAD TARALLI}

Professora Doutora nos cursos de Arquitetura e Urbanismo e Design da Universidade de São Paulo. Orienta pesquisas em: metodologia e processos de pesquisa e de projeto; fabricação e montagem de produtos em design e arquitetura; linguagem e representação.

Professor of Architecture and Urbanism and Design at the University of São Paulo. Her research interests include methodology and processes of research and project; manufacturing and assembling products in design and architecture; language and representation.

cibelet@usp.br

lattes.cnpq.br/

6016190566941978

\section{PAINÉIS ACÚSTICOS MÓVEIS: PEQUENOS ESTÚDIOS E DIFERENTES CONFIGURAÇÕES ACÚSTICAS POR MEIO DO DESIGN}

\author{
MOVING ACOUSTIC PANELS: SMALL STUDIOS AND DIFFERENT \\ ACOUSTIC CONFIGURATIONS THROUGH DESIGN
}

\section{PALAVRAS-CHAVE: DESIGN ACÚSTICO; ACÚSTICA DE ESTÚDIOS DE ÁUDIO; DESIGN E MOVIMENTO; SIMULAÇÕES ACÚSTICAS; CONFIGURAÇÕES MODULARES \\ KEYWORDS: ACOUSTIC DESIGN; ACOUSTICS OF AUDIO STUDIOS; DESIGN AND MOVEMENT; ACOUSTIC SIMULATIONS; MODULAR SETTINGS}

O projeto de pesquisa tem por objetivo, investigar avaliar e discorrer de forma dissertativa sobre processos de desenvolvimento de projetos de design em acústica, voltados para espaços de produção musical gravada ou a ser reproduzida tanto por mídia física como ao vivo/gravado por meio digital na web, limitando a pesquisa de campo a um recorte geográfico circunscrito à cidade de São Paulo, tendo a abrangência da pesquisa em duas faixas, a saber: estúdios profissionais de porte médio/pequeno e home studios de produtores independentes. $O$ desenvolvimento da pesquisa, em uma segunda etapa, pretende elencar critérios de desempenho de salas acústicas em três situações: para tomada de áudio de instrumentos acústicos, voz e instrumentos eletrônicos não gravados em linha (tomada de gravação direta captada por microfones, onde a sala entra como extensão do instrumento), salas técnicas, onde são processadas as tomadas de gravação e salas de audição crítica, onde são avaliados resultados pós-mixagem e pós- masterização do produto. Em uma terceira etapa, será realizada análise crítica sobre os dados coletados e pretende avançar sobre o projeto espacial e geometria, design de peças de mobiliário acústico (painéis manufaturados, produzidos industrialmente ou impressoras 3D) suas características e resultados, bem como sobre design de mobiliário específico para estúdio e do mobiliário de suporte e decoração, enfatizando o Design, no projeto e metodologias de pesquisa voltadas a produção de objetos acústicos que venham compor configurações de espaços sonoros em etapas diversas do processo de produção de áudio em estúdio e objetos de suporte acústico para tomadas de gravação de vozes ou instrumentos específicos, baseados na literatura, prática profissional e demandas de mercado.

The research project aims to investigate and discuss in a dissertation way the development processes of design projects in acoustics, focused on spaces of recorded music production or to be reproduced by both physical and live / digitally recorded media in the. web, limiting the field research to a geographic cut circumscribed to the city of São Paulo, having the scope of the research in two tracks, namely: medium / small professional studios and home studios of independent producers. The development of the research, in a second stage, intends to list performance criteria of acoustic rooms in three situations: for audio recording of acoustic instruments, voice and electronic instruments not recorded in line (direct recording socket captured by microphones, where the room extension of the instrument), technical rooms, where the recording jacks are processed and critical hearing rooms, where post-mixing and post-mastering results of the product are evaluated. In a third step, a critical analysis will be performed on the collected data and it intends to advance on the spatial design and geometry, design of acoustic furniture pieces (manufactured panels, industrially produced or 3D printers) their characteristics and results, as well as on furniture design. specific to studio and supporting furniture and decoration, emphasizing Design, design and research methodologies focused on the production of acoustic objects that will compose sound space configurations in different stages of the studio audio production process and acoustic support objects. for voice recording jacks or specific instruments, based on literature, professional practice and market demands. 